\title{
MARÍA ALEJANDRA GARBINI \\ (1959-2004)
}

El 10 de octubre de 2004 falleció la Lic. María Alejandra Garbini. Había nacido en Buenos Aires el 16 de septiembre de 1959.

Cuando en el año 2001, por razones de capacitación en el manejo del programa de edición de revista, visité el Instituto Darwinion, conocí a la Licenciada Garbini, encargada del armado y compaginación de la revista Darwiniana perteneciente al Instituto. Profesional seria y cuidadosa, Alejandra se brindó con cordialidad y espontaneidad. Tiempos difíciles éstos para encontrar tanta gene-

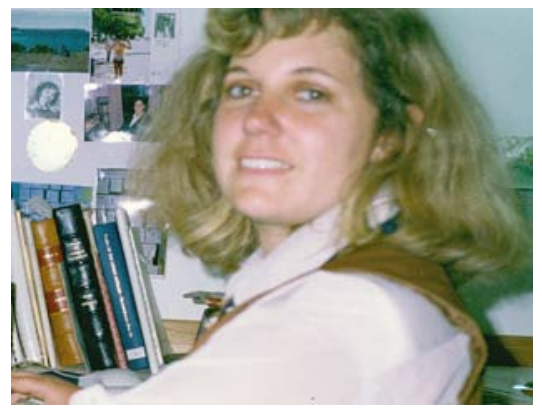
rosidad de conocimientos propios, más destacable aún cuando los ofrecía a quien acababa de conocer.

Cada vez que un trabajo de Bonplandia comienza a editarse, rememoro a Alejandra. Su buen trato, consejo, dedicación, están presentes. Por ello van estas líneas que espero expresen de alguna manera mi gratitud y afecto hacia ella. 